\title{
Spinning the Threads of Discontent
}

$\mathrm{T}$

RAVELERS TO I920S SHANGHAI found themselves captivated by the sights and sounds of a modern city powered by electricity. Electric street lamps had been illuminating the Bund, Nanjing Road, and Broadway since I883, and Shanghai's architectural internationalism was on display all day and night. City lights accentuated the beauty of the European-style buildings throughout the Bund and French Concession and electric tram lines zipped through the International Settlement. There was never a dull moment at night. Shops lit up their signboards with neon lights; restaurants and dance halls welcomed customers late into the night; theaters dazzled the audience with the astute use of lighting in their performances.

Where did the energy that fueled Shanghai's prosperity come from? Follow the map in figure I.I to locate Shanghai's engine room. Turn away from the bright lights on the Bund. Cross Suzhou Creek on Garden Bridge (now known as Waibaidu Bridge), walk along Broadway, then continue east onto Yangshupu Road. The "Paris of the Orient" fades into the background as one ventures into the "Manchester of the East." One would pass by numerous cotton mills on both sides of Yangshupu Road and see a few others along Ward Road, which runs parallel to Yangshupu Road. Steam and coal ash permeates the air. Some of that ash comes from the chimneys of cotton mills, as workers fed coal in the furnaces to keep the old steam engines and generators chugging along. Some comes from the Riverside Power Station on the eastern end of Yangshupu Road. In fact, Chinese, Japanese, and British cotton mills were the largest clients of this power station, which was completed in I9I2 and controlled by Shanghai Municipal Council up until 1929.

This hypothetical journey from the Bund into the Eastern Textile District traces the developmental trajectory of electrical power in Shanghai. The lights in Shanghai, which captured the imagination of Chinese novelist Mao Dun and Japanese writers who visited Shanghai, such as Akutagawa Ryūnosuke and Tanizaki Jun'ichirō, served as the spark that led to the creation of the city's 


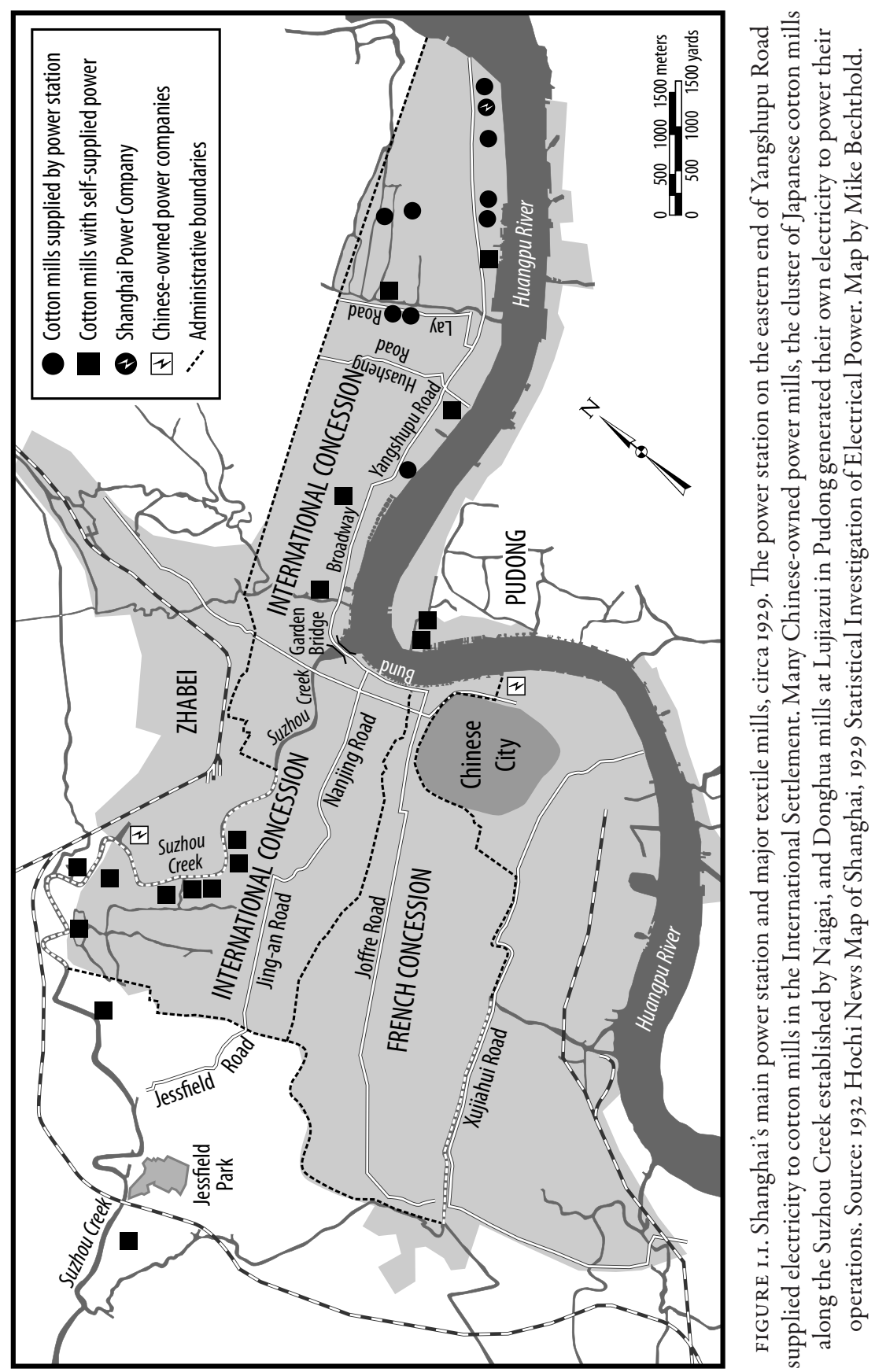


electrical power systems. Had Shanghai's electrical industry relied solely on electric lighting for its revenue, it would have died an early death. It was the huge power demand from cotton mills that catalyzed the expansion of Shanghai's electrical infrastructure. The struggle over access to electrical power became a key aspect of the commercial warfare raging between Chinese and foreign cotton mill owners. ${ }^{1}$ Its outcome shaped the pattern of accelerated economic development under conditions of capital scarcity, inspired conceptions of economic sovereignty, and generated residual inefficiencies that had broad environmental implications.

A journey into the engine room of China's early industrialization not only allows us to track the development of Shanghai's electrical infrastructure alongside its key industries, but it also exposes problems created by the uneven pace of technological development. The mechanization of cotton production had begun before the introduction of electricity. Shanghai's first cotton mills were set up in 1878, four years before the first power station was built. The first generation of cotton mills installed their own power-generation equipment, as the generating capacity of power stations was too low to meet their demands. The vast expansion of Shanghai's electrical utilities after 1914 did not lead to the end of the "selfsupplied power" operational model. Japanese cotton mills became the greatest beneficiaries of this newly available source of electricity, while Chinese plant owners maintained the practice of generating their own electricity, or even installed obsolete machinery hooked up to steam engines. The persistence of obsolescence contributed to residual inefficiencies within Shanghai's textile industries.

Self-supplied power sheltered Chinese cotton mills from the vagaries of the "transnational colonialism" within the Shanghai Municipal Council (SMC). I concur with Isabella Jackson that the colonial nonstate actors from different nations within the British-dominated SMC cooperated in a manner that transcended their own national interests. ${ }^{2}$ That said, the SMC remained prone to accusations of restricting Chinese businesses from accessing public utilities. This multinational cooperation also broke down during the May Thirtieth Movement in 1925 , as the British used electricity as a bargaining chip to force a resolution of the strike. Interestingly, Chinese cotton mills that had been denied access to the power grid and installed their own power equipment were able to resume operations faster than the cotton mills that depended on the Electricity Department for their power supply.

The mechanization of cotton milling in China has a profound environmental impact, triggering China's transition from an organic economy to a carbon-based one. While I agree with Sven Beckert's assertion that "cotton became the 
launching pad for the broader Industrial Revolution," I take issue with his claim that China and India became more "subservient to the Europe-centered empire of cotton." The electrification of cotton milling in China set the stage for the Great Acceleration of the Anthropocene, during which the massive expansion of human economic activity impacted the functioning of the Earth system at the global level. This chapter addresses Amitav Ghosh's question: "Could it be the case that imperialism actually delayed the onset of the climate crisis by retarding the expansion of Asian and African economies?"' I contend that imperialist forces were responsible not only for introducing the carbon-intensive modes of industrial production by financing Shanghai's cotton industries but also for creating the inequalities that increased the energy burden of China's textile industries.

\section{From Light to Power, I882-I915}

Shanghai's fragmented power industry mirrored its urban politics. Located in Shanghai's International Settlement, China's first power station began operations on July 26, I882. In that very year, Thomas Edison lit up Wall Street with direct-current generators at the Pearl Street Power Station. The former chairman of the Shanghai Municipal Council Robert Little raised funds to convert a warehouse at the intersection of Nanjing East Road and Jiangxi Road (near present-day Nanjing East Road Subway Station) into a small power station outfitted with a $16 \mathrm{~kW}$ direct current (DC) generator.

New entrants swooped into Shanghai's electrical power market in 1897 and I9II to capitalize on its huge growth potential. The French Concession established its power station at Yangjingbang in 1897 , then in 1906 it merged the power company with the tramway company to establish the Compagnie Francaise de Tramways et d'Eclairage Electrique de Shanghai. The Qing government built the South City Power Company in 1898 , which was then sold to Chinese businessman Li Pingshu and his partners in 1906. The South City Power Company later merged with Chinese Merchants Tramways Company in 1918 and was reincorporated as the Chinese Merchants' Electric Company. In October I9II, Li Pingshu completed the construction of Zhabei Electric and Water Works in the Chinese-controlled Zhabei district. ${ }^{5}$ Having carved up Shanghai into separate franchise areas, these late entrants started out with electrical illumination as their main revenue source, but diversified their client base by supplying electricity for industrial use. In 1907, 92 percent of the electrical power sold in Shanghai went toward public and private lighting. By 1935 nationwide, electric light only 
accounted for 25 percent of power consumption $(390,307 \mathrm{kWh})$, while electrical power amounted to 57 percent $(892,046 \mathrm{kWh})$. The remaining I8 percent was lost via power transmission. ${ }^{6}$

Electric lighting faced stiff competition from gas and other alternatives, which limited its scope for growth. Yang Yan's research shows that the first generation of electric arc lamps were less cost competitive than gas lamps. In February 1883, Little placed a bid to replace I5s gas lamps along Nanjing Road, the Bund, and Broadway with thirty-five arc lamps at an annual cost of 9,100 taels of silver. The gas company counteracted by placing a competing bid for sixty-two new gas lights with an annual cost of 4,542 taels. While the number of arc lamps increased from thirty-five in 1883 to eighty-one in 1892 , the number of gas lamps at this time also went up from 398 to 483 . Up until I892, the cost of gas lighting was about 40 percent lower than electric lighting. Little's Shanghai Electric Company suffered from manpower and capital shortage and was unable to promptly repair broken generators and arc lamps. It was reincorporated in I888 and was acquired by the Shanghai Municipal Council in August 1893. ${ }^{8}$ The cost of electric lighting went below that of gas lighting that same year when the Shanghai Municipal Council assumed ownership of the power company.

The newly emergent alternating current (AC) system contributed to the expansion of the power generation network. In DC systems adopted by the early power companies, voltage fell significantly when the current traveled for more than one mile. Little could have tried to resolve the problem of transmission loss by moving his small power station half a mile north to another warehouse in Zhapu Road. As Ernest Freeberg pointed out, AC systems developed by Westinghouse and the Thomson-Houston companies began to displace Edison's DC system by 1889 , as they were much more efficient and flexible. ${ }^{9}$ Transmitting alternating current at a high voltage reduced line loss. The network of transformers could safely step down the voltage for safe use by consumers. Placed under municipal ownership, the Shanghai Power Company adopted the AC system when it established a new power station on Fearon Road (present-day Jiulong Road), which was completed in 1896 . The electrical power network in Shanghai expanded rapidly, and the electrical engineer of Shanghai Municipal Council T. H. U. Aldridge reported that the mileage of electrical mains increased by 210 miles between 1903 and 1907 , reaching a total of 400 miles by $1907 .{ }^{10}$

Revenue growth from electric lighting began slowing down during this period of rapid expansion. Between 1883 and 1907 , the number of arc lamps lighting Shanghai's streets increased from 35 to 238 . Average revenue growth from energy-intensive arc lamps fell a few years after 1886 . Between 1882 and $\mathrm{I} 893$, the 
number of arc lamps increased at an annualized rate of 19.2 percent. ${ }^{11}$ Revenue per lamp peaked at 253 taels in 1886 , remained stagnant for a few years, then steadily declined to 140 taels in $1893 .{ }^{12}$ The annualized rate of increase decreased to 4.0 percent for the next thirteen-year period (1893-1906). In 1907, only eleven additional arc lamps were erected. ${ }^{13}$ Residential lighting and smaller street lamps that used less electricity became increasingly popular but did not help the power company boost its revenue. Lighting the side streets and outlying roads of Shanghai were 736 incandescent lamps. Between 1900 and 1907, the number of lights installed grew at an annualized rate of 32.6 percent, but electrical power units sold only grew by 22 percent. ${ }^{14}$ Electrical illumination alone would not deliver the high revenue growth that would fuel further expansion of the power sector.

The British-controlled Municipal Council identified industrial electricity as a promising growth sector. In his December 1907 report, Aldridge noted that the sale of "electricity for power purposes" grew by II 4 percent to I 4I,I 46 units $(\mathrm{kWh})$ and stated: "The development of the power load during the daytime, when the lighting demand is comparatively small, is to be encouraged by all possible means, because of the important part it plays in improving the load factor of the station, which in turn indirectly assists in cheapening the cost of production." ${ }^{15}$ Aldridge had every reason to be optimistic. In 1907, the number of electric elevators in Shanghai's Financial District more than doubled within a year from ten to twenty-three. The harbors in the Eastern and Central districts also employed electric hoists to handle cargo. A larger generator was installed following the expansion of the Fearon Road Power Station, which gave an additional boost to the Shanghai Tramways. Electric motors seemed to be opening up new revenue streams.

Aldridge's 1907 report outlined the most ambitious expansion of Shanghai's electrical power infrastructure and signaled the rising importance of industrial power use. The Municipal Council chose to build the new power station at Yangshupu-the center of Shanghai's textile industries. Located on the eastern edge of the International Settlement and along the Huangpu River, the Riverside Power Station at Yangshupu had a superior location compared to the Fearon Road Power Station, which had "no conveniences for coal and a very poor supply of water for condensing purposes. The barging of coal, especially in winter, is a difficulty and all coal had to be carried into the works in baskets and already 300 baskets come in every day. ${ }^{\prime 16}$ The Municipal Council was optimistic about the growth prospects, which is evident from Aldridge's description that the "station should be laid out to accommodate 5,000 kilowatts in plant, but so arranged to permit indefinite extensions as required."17 
Aldridge engaged the services of Arthur H. Preece-the son of William Preece, the engineer-in-chief of the British post office who was himself a globe-trotting partner of the electrical and telecommunications firm Preece \& Cardew. Projected power demand was so high that Preece proposed installing two turbo-generators of $\mathrm{I}, 500 \mathrm{~kW}$ each, instead of $\mathrm{I}, 000 \mathrm{~kW}$ each as previously planned. Shanghai's load factor was comparable to Coventry and West Ham in England, so there was no need to worry about overcapacity. Preece, who had managed electrical utilities in Calcutta, estimated that Shanghai Power would recoup the cost within two and a half years. Shanghai's power grid relied on high-voltage overhead lines, which were cheaper than the partially underground system in Calcutta. ${ }^{18}$

Outside of Shanghai, China's earliest power stations started out with electric lighting as their core business and then began promoting the use of electric motors. The first power stations established by Chinese businessmen followed the "government-supervised, merchant-managed" model that emerged from the self-strengthening movement. In 1890 , Huang Bingchang, a Chinese businessman living in the United States, sought approval to build the Canton Electric Light Company. Zhang Zhidong, the governor-general of Guangdong and Guangxi and a leading self-strengthener, duly approved his request. When Huang's illumination company failed in 1905 , the Qing government acquired it and merged it with another foreign-owned power station to form Guangzhou Electric Company. Of the thirty-three power stations founded before I9II solely on Chinese capital, twenty-seven registered themselves as diandeng chang (illumination companies). ${ }^{19}$ The remaining six referred to themselves as dianqi gongsi (power companies) or fadian chang (power stations), but they were reincorporated from other diandeng chang. One example of an early adopter who saw the potential for electricity to become a general-purpose technology was located in Wuhu, Anhui Province. Wu Xingzhou from Hefei amassed some wealth from selling sundry goods. He had set up Mingyuan Electric Light Company in Wuhu, Anhui Province, in 1906. Plowing the profits from electric lighting, Wu Xingzhou went on to build a flour mill, matchstick factory, machine works, telephone exchange, and other industries. ${ }^{20}$ The diversification of electric companies catalyzed industrialization in places beyond Shanghai as well.

\section{Energy Revolution in Textile Production}

Back in Shanghai, cotton mills became the largest consumer of electrical power within a few years of the completion of the Riverside Power Station in I9I2. Even with their wildly optimistic projections, Preece and Aldridge grossly 
underestimated Shanghai's power needs. Older cotton mills continued to generate their own electricity with in-house steam engines, as their old machines ran on a different power rating than that supplied through the grid. Japanese cotton mills, founded at the moment when Shanghai expanded its electrical power-generating capacity, capitalized on the new sources of cheap and abundant electricity. Only a few Chinese-owned cotton mills switched to purchasing electricity from the grid. Many of them, however, arrived on the scene a little too late and resorted to the preexisting practice of generating their own electricity. They either acquired obsolete machinery powered by steam engines or simply had their applications to connect to the grid rejected by the power company. Unequal access to electricity became a source of contention between Chinese and foreign textile mills.

The mechanization of cotton textile production in China was well underway even before the introduction of electrical power. By the late nineteenth century, the influx of machine-spun cotton yarn from India had displaced hand-spun cotton yarn in China. As Tomoko Shiroyama noted, the coarse and durable yarn was so popular that farmers in the cotton-producing region of the Lower Yangtze bought Indian yarn to weave cloth for sale. ${ }^{21}$ At the same time, the reformers of the self-strengthening movement called for the establishment of cotton mills as part of an effort at import substitution. In 1878 , the leading reformer Li Hongzhang founded the Mechanized Textile Bureau under the "government-supervised, merchant-managed" model. Equipped with 530 looms and 35,000 spindles imported from the United States, the first state-sponsored cotton mill began operations in 1889 . In I893, after a fire destroyed the machinery, official-industrialist Sheng Xuanhuai took over the cotton mill and incorporated the Huasheng Company. ${ }^{22}$ One of its subsidiaries was Huaxin Spinning Mill founded by the Shanghai Circuit Intendant Gong Zhaohuan in $1888 .{ }^{23}$ The Dasheng Number I Cotton Mill, which is the subject of Elisabeth Köll's study on regional enterprises, was founded in 1895 by scholar-official Zhang Jian under official patronage. ${ }^{24}$ Between 1895 and 1914, Chinese, British, and Japanese businessmen established ten cotton-spinning mills in Shanghai, which led to a massive increase in power demand.

Existing power stations, however, did not generate enough power for industrial use. Even after its reincorporation in 1888 , the peak instantaneous power output of Shanghai Power Station was $150 \mathrm{~kW}$, which was less than half the needed power of the smallest cotton mill in Shanghai. ${ }^{25}$ Tongchang Xieji, which was equipped with only 2,000 spindles, installed a $350 \mathrm{~kW}$ steam engine to drive its machinery. ${ }^{26}$ Cotton mills farmed out the repair, maintenance, and operation 
of the steam engine to a mechanic known as a laogui (old devil). The cotton mill paid the laogui a monthly wage based on the number of reels installed. ${ }^{27}$ Furthermore, the earliest generation of alternating current technology was not suited for industrial use. The Fearon Road Power Station generated a single-phase AC at 2,200 volts. Single-phase power systems deliver pulsating currents, which is incompatible with textile machines that ran at a constant rate. Single-phase AC systems also needed more conducting material, which made it costly to expand the electrical power network. The low-generating voltage meant that the power could only be transmitted for a short distance. The Fearon Road Power Station was too far from the cluster of cotton mills on Yangshupu Road for power transmission to be economical.

When the Yangshupu Power Station entered operations in 1912, the Shanghai Municipal Council began promoting the electrification of industries within the International Settlement. Hengfeng Cotton Mill, which had started out as Huaxin Spinning Mill, was one of the first cotton mills to acquire electricity from the grid. Its general manager, Nie Yuntai, was the grandson of the self-strengthening reformer Zeng Guofan. According to David Faure, his father, Nie Jigui, began accumulating shares in Huaxin after taking over as the circuit intendant of Shanghai in 1890 and acquired a two-thirds stake in the company by $1905 .{ }^{28}$ The Nie family took control of Huaxin in 1909 when it was auctioned off. Nie Yuntai saw the transition away from steam engine to electrical power as a means to wrest operational control away from the laogui and improve product quality. The driving force for the looms became uneven when the temperature of the steam engine fluctuated, which made the yarn quality uneven. Nie eliminated the problem by acquiring fifteen electrical motors with a total power rating of 554 hp and Hengfeng's coarse yarn with a thread weight of $16 s$ became the standard product for transactions in the Shanghai Cotton Exchange. ${ }^{29}$

Japanese cotton mills entered the scene just as the new power station came online and took advantage of this new mode of production. Established in 1914 as a joint venture between British, Japanese, and Chinese businessmen, the Shanghai Spinning Factory with about 30,000 spindles initially relied on a $3,200 \mathrm{~kW}$ steam engine to power its operations. As it tripled the production capacity and branched out into cloth weaving, Shanghai Spinning Factory began purchasing electricity from the Riverside Power Station..$^{30}$ Electricity was a major cost component. For example, a Japanese textile mill equipped with Toyota cotton looms spent about $\mathrm{I}, 200$ sterling pounds on electricity, amounting to 2.8 percent of its total cost. ${ }^{31}$ Japanese mill owners shifted production to Shanghai, not only to lower production cost and evade the threats of tariffs against Japanese goods, ${ }^{32}$ 
but the availability of cheap electricity was also a contributing factor. Shanghai's electric tariff rate (2.5 pennies per unit) was 37.5 percent lower than that of Calcutta and comparable to London. ${ }^{33}$ By 1914, power and heating overtook electric lighting as Shanghai Power Company's main revenue source, largely driven by demand from new Japanese cotton mills. ${ }^{34}$

Many existing cotton mills continued to use preexisting steam engines and generators and did not make the switch to purchasing electricity from the power company. According to the National Statistical Investigation of Electrical Power Industries collected by the National Construction Commission in 1929 and data compiled by the Union of Chinese Cotton Mills in 1933, all Chinese and foreign textile mills set up before 1915 continued to generate their own power. ${ }^{35}$ The Sino-British Textile Bureau, cofounded by Jardine, Matheson \& Company and local Chinese merchants in 1895 , retained its $3,100 \mathrm{~kW}$ steam generator to supply its own electrical power well into the 1930s. ${ }^{36} \mathrm{Up}$ until 1929, a total of 600,000 spindles across China were still running on steam power. Zhang Wangliang, an electrical engineer who worked in cotton mills, noted that cotton mill owners knew that it was cheaper to purchase electricity from the power company but were reluctant to change for four reasons. First, an electrical motor had a lower power rating than the steam-powered machines but was more expensive. Second, the installation cost was high. Third, electric motors were more expensive to maintain. Finally, it was wasteful to abandon the flywheels, cables, and belts from the old machines. ${ }^{37}$ Obsolete machinery persisted because it was still the most cost effective technology for small cotton mill owners grappling with capital shortage.

Cotton mill owners who purchased electricity from the power company had to contend with disruptions due to breakdowns and power shortages. The Riverside Power Station reported severe breakdowns within two years of its completion. In January 1915, the turbine blades of generators number I and 2 broke off. Generators number 3 and 4 burned out in September and October 1917. The power company alleviated the shortage by installing a fifth generator set with a I0,000 kW capacity. Due to World War I, the power company waited until I919 to ship the damaged number I and 2 generators to Japan for repairs, while the delivery of two generator sets from Britain had to be delayed until $1920 .{ }^{38}$ The power company was also unable to keep up with new demand. Eight more Chinese cotton mills founded between 1918 and 192I with a total of 246,000 spindles established in-house electrical units to ensure energy self-sufficiency. ${ }^{39}$ Hengfeng, one of the first cotton mills that connected to the power grid, expanded its operations after World War I to cater to increased demand. Hengfeng added 164 cloth weaving machines and more than 23,000 spindles when it 
opened a new plant in 1921. Seeing that the power station failed to meet additional demand, Hengfeng also installed $2,198 \mathrm{~kW}$ of generating capacity. Of the ten British and Japanese mills in Shanghai, only four of them installed their own generators or steam engines, while the rest received their electricity from the power grid. In comparison, sixteen out of twenty-eight Chinese-owned textile mills generated their own power. ${ }^{40}$

Chinese mill owners gauged their energy demand by referencing the experience of similar cotton mills in Japan. Both Japanese and Chinese mills manufactured coarse yarn with a thread density below 30 s by spinning short-fiber raw cotton from India and China. ${ }^{41}$ One of the most detailed estimates of energy input published in Chinese was based on the records of a single day's production by factory manager Sugimoto Aki of Minoshima Cotton Mill at Wakayama Prefecture, Japan. Sugimoto derived the energy efficiency with a few known variables-quantity of $205,305,32 \mathrm{~s}$, and 40 s yarn produced and the total energy consumption of the day. He proceeded to subtract electrical energy used for worker dormitories and lighting and assumed that the rest of the electricity went toward powering the machinery. He then determined the average revolution per minute of the front rollers of the drawing frames based on all these variables. After finding out the electrical energy expended in the preliminary stages of drawing, Sugimoto went on to the calculations for the slubbing, intermediate, roving, spinning, and winding processes. The result showed that one bag of $20 \mathrm{~s}$ cotton yarn ( $406 \mathrm{lbs}$ ) required $265 \mathrm{kWh}$ of electricity, that of 305 yarn and $40 \mathrm{~s}$ yarn being $397 \mathrm{kWh}$ and $520 \mathrm{kWh}$ respectively. ${ }^{42}$ The estimate served as a reference for mill owners to select a generator with appropriate power ratings to run their operations. That said, the calculations from Sugimoto's energy accounting exercise could not be applied universally. Variations in cotton fiber length, roller rotation speed, machine component weight, and cotton yarn fineness meant that every cotton mill faced different energy needs.

Most notably, Chinese cotton with its shorter average fiber lengths required more energy to process. ${ }^{43}$ Analyzing Sugimoto's calculations in relation to the information from the 1906 International Library of Technology textbook helps to explain why this is the case. The short length of the fibers required a shorter distance between the roller pairs. For comparison, the distance between the bottom rollers for American cotton was I 1/4 inches, while that of Egyptian and Sea-Island cotton was $\mathrm{I} 3 / 8$ inches. The roller setting for Chinese cotton was shorter at $7 / 8$ to $1 \frac{1}{8}$ inches. Assuming that the weight of the components was the same, the rollers working on Chinese cotton would have to complete more revolutions per minute to spin the same length of yarn. 
Many cotton mills continued to assume the risk of generating electricity in-house instead of purchasing power from the electric company. Cotton mills directly bore the fuel and maintenance cost. Coal prices in Shanghai were double that in Calcutta, most likely the result of Japanese conglomerate Mitsui Bussan cornering the coal supply. ${ }^{44}$ Production had to be put on hold when the generators were shut down for routine maintenance, and electrical units were prone to accidents. In May 1926, the electrical unit in the Japanese-owned Xihe Cotton Mill blew up, killing one and injuring four others. The explosion was so strong that it burned through five-inch-thick steel plates. Two Japanese technicians had their fingers severed during the accident but managed to survive. ${ }^{45}$

\section{Electricity as a Bargaining Chip}

In the summer of 1925 , cotton mill owners who were increasingly relying on recently expanded power stations for electricity realized that the new technology came with political risks. On May 30, 1925, Shanghai municipal police shot and killed a number of demonstrators who protested the ill-treatment of Chinese workers in Japanese-owned textile mills. Known as the May Thirtieth Movement, this incident is remembered as an anti-imperialist labor movement. It also marked the first instance when electrical supply was used as a bargaining chip in a political crisis. Cotton mills at the center of the labor unrest saw their operations grind to a halt when the Shanghai Municipal Council imposed a power blockade on the city's industries. Chinese-owned cotton mills that maintained the older practice of generating their own electricity, however, were able to partially continue their operations amid this political crisis.

The Shanghai Municipal Council quickly secured the public utilities upon the first signs of unrest. Shortly after the declaration of a state of emergency on June I, 1925, an American naval party moved in to protect the Riverside Power Station and waterworks the next day. Thirteen hundred Chinese power station workers joined the general strike on June 4 . They were among the 200,000 workers across two hundred enterprises who participated in a months-long stoppage in the summer of $1925 .{ }^{46}$ The Electricity Department hired one hundred Russian workers as strikebreakers to keep this essential service operational. Chief engineer Aldridge intended to retain thirty of these workers and fire forty-six striking Chinese workers to "form a nucleus that can be depended upon in the event of future industrial action. ${ }^{, 37}$ By June 29, 1925, the Electricity Department decided to discontinue power to all consumers except food producers on July 7 at noon, citing labor shortages. Harumi Goto-Shibata pointed out that the British 
minister in Beijing, C. M. Palairet, used the termination of electrical power to pressure Chinese authorities into dealing with agitators hoping that it would resolve the strike. ${ }^{48}$ The Chinese in the International Settlement sought the assistance of the Italian consul-general de Rossi, whose empty threats directed at the Municipal Council were duly ignored. ${ }^{49}$

The power blockade severely crippled Shanghai's cotton industry. Two months of work stoppages caused Chinese cotton mill owners to sustain a loss of 3.26 million Chinese dollars. Five Chinese cotton mills equipped with their own generators resumed production in July and sold about 285 bags of coarse yarn per week. But with 500,000 spindles taken offline, production capacity was reduced by 1,000 bags per day. ${ }^{50}$ Japanese-owned mills bore the brunt of the losses, and between July 16 and 27, Hsu Yuan, the Jiangsu provincial commissioner for Foreign Affairs in Shanghai, negotiated with Japanese consul-general Yada Shichitaro to settle the strike. ${ }^{51}$ As the Chinese and Japanese came closer to breaking the deadlock, Japanese mill owners pushed for the resumption of electrical power before the workers returned to work. The Electricity Department, however, adhered to its policy of supplying electricity only when the strike came to a complete end and rejected the request from the Japanese councilor $S$. Sakuragi. ${ }^{52}$ On August II, Japanese mill owners and Chinese workers arrived at a compromise. One of the six conditions was "that those mills having electrical power are to resume operation at once. In those which were dependent upon the Electricity Department for power, workers should resume work as soon as power is furnished in them." ${ }^{33}$ The inclusion of this provision was meant to prevent workers from collecting wages when the mills were not yet operational.

The British insisted on using their leverage on their control over electrical power to delay the resolution of the strike. Chief engineer Aldridge once again turned down the Japanese request to resume power on August 13, stating that "until the departmental employees have resumed duty upon the Council's own terms, it is impossible to restore supply." ${ }^{\prime 4}$ At this point, the British sensed that a labor dispute that resulted from Japanese ill-treatment of Chinese workers was turning into an anti-British boycott. The Chinese and Japanese had settled their differences, but the standoff within British industries was not over. In a memorandum dated August 2I from the British consul-general to Shanghai Sidney Barton addressed to the British legation in Beijing, Barton rejected any arrangements that "enabled the Japanese mills to reopen while the British mills were closed and a purely anti-British strike maintained." In this document, he concluded by calling the power supply a "most effective weapon," which "may yet be retained for use by increasing the volunteer labour sufficiently to supply 
the Japanese mills, while refusing to supply the Chinese mills until normal conditions return." He also scornfully dismissed the threats from the Japanese Mill Owners' Association to boycott the Municipal Electricity Department and set up their own plant and reiterated his point that "the incident of May 3oth arose from the protection offered by the Municipal Council to Japanese interests against the anti-foreign and particularly anti-Japanese agitation, arising out of the Japanese mill strike." ${ }^{55}$ Hsu Yuan, who had resolved the conflict between the Japanese mill owners and Chinese workers, offered to persuade the Chinese electrical workers to return to work unconditionally on August 26, but the Electricity Department insisted on the termination of two hundred Chinese workers and the retention of the Russian strikebreakers. ${ }^{56}$

Within days of Barton's saber-rattling, it became clear to the British councilors that the strategy of holding up the electrical supply was no longer tenable. Council Chairman Stirling Fessenden warned that the discontinuation of the power supply had caused the Chinese and other foreign powers in Shanghai to see the Municipal Council as an agency that furthered British interests. He concluded: "Any impression therefore that the Council was acting in the interests of any one national would undoubtedly be read as a further argument by the Powers interested for revision of the present form of Municipal administration. He therefore suggested that a reply should be forwarded to the Commissioner for Foreign Affairs to the effect that when all the workers required have returned to duty, the Council will restore the power supply." ${ }^{\prime 57}$ The British backed down and withdrew their stipulation for the firing of two hundred electrical workers but conveyed their intention to discharge the workers whose services may no longer be needed. The British-led Municipal Council resumed electrical supply on September 8, a full eighteen days before persuading the workers to resume work at the British mills. ${ }^{58}$

Shanghai's cotton industries experienced a sharp downturn after the May Thirtieth Incident. Japanese yarn flooded the Chinese market when Shanghai's cotton mills ceased production. Distributors even removed the Japanese brand labels and marketed them as Chinese-made products to get around the boycott of Japanese goods. A number of Japanese mills closed down in the aftermath of May Thirtieth. The number of cotton mills fell from twenty-six to twenty-two in 1925 , then rebounded to twenty-four in 1927.9 Between the Guomindang's campaign in Shanghai in April 1927 and early 1929, no new cotton mills were founded in Shanghai. Frequent strikes crippled the transportation networks and hampered further expansion of the Riverside Power Station. Despite the sharp downturn in Shanghai's cotton industry, power demand from other industries bolstered the revenue of the Electricity Department. 
In the wake of industrial unrest, the Shanghai Municipal Council made plans to sell the Electricity Department, even though it contributed most of the government's revenue. A. W. Burkill, who chaired the Electricity Special Committee, explained that the sale would ensure that the provision of electrical power would be "regarded purely as an industrial concern and beyond the scope of political influence." ${ }^{00}$ Burkill saw the corporatization of electrical power as a way to maintain cheap and abundant electricity in Shanghai and dispel the distrust stemming from the Municipal Council's handling of the May Thirtieth Incident. The huge growth potential of Shanghai's power market meant that the Municipal Council was able to sell the Electricity Department at a good price. By the late 1920s, the Shanghai Power Station was selling more power units and achieved a higher load factor than the Manchester Power Station in Britain. On April 1929, the Municipal Council passed a resolution approving the sale of the Electricity Department to American-owned Electric Bond \& Shares Company Limited for 8I million taels of silver. With its financial future secured, the power company quickly completed the installation of a medium-pressure boiler and raised the power station's capacity to $161,000 \mathrm{~kW} \cdot{ }^{61}$ Renamed the Shanghai Power Company, it was poised to enter a new period of accelerated growth.

Four new cotton mills in Shanghai that opened up in 1929 became potential customers for the newly incorporated power company. Shenxin Number 8 mill and Xiefeng Yiji did not adopt the self-supplied power model and chose to purchase electricity from the grid. ${ }^{62}$ In an advertisement published in the 1932 edition of the China Cotton Journal, the Shanghai Power Company proclaimed that it supplied Shanghai's industries with "more than 193,000 h.p. of electricity," and it was "the only company in Shanghai that was capable of supplying such a [large amount of] electrical power." ${ }^{33}$ Outside the International Settlements, cotton mills also began to acquire electricity from the grid. Hengda Cotton Mill at Pudong made this transition. It had relied on a $500 \mathrm{~kW}$ generator at its facility because there was no power station in the vicinity when it started operations. When Pudong Electrical Power was founded in 1932, Hengda purchased power directly from the local company and stopped generating power in-house. ${ }^{64}$

Not every new cotton mill followed the example of Shenxin Number 8 and Xiefeng Yiji. Longmao Cotton Mill, established in 1929 by a certain Mr. Yang, acquired the assets of Japanese-owned Tōka (Donghua) Number I mill that had been founded in $1920 .{ }^{65}$ Built during a time when the Riverside Power Station was unable to keep up with power demand, Tōka Number I supplied its own electricity with a $1,250 \mathrm{~kW}$ generator with an output voltage and frequency of $600 \mathrm{~V}$ and $60 \mathrm{~Hz} .{ }^{66}$ Shanghai Power Company supplied a three-phase 
alternating current supplied at $220 \mathrm{~V}$ and $50 \mathrm{~Hz}$, which was incompatible with Longmao's machinery. Yang raised six million Chinese dollars to replace the equipment to match the cost efficiency of other cotton mills that took advantage of cheap electrical power from the grid. Before the equipment upgrade was complete, Shanghai suffered massive aerial bombardment when Japanese and Chinese forces clashed between January 28 and March 3, 1932. Situated near the conflict zone, Longmao suffered massive losses and liquidated all assets in 1932 upon bankruptcy. ${ }^{67}$ Longmao's collapse illustrated how undercapitalization forced small Chinese-owned textile mills to adopt obsolete technology to save on equipment cost, thereby condemning them to less efficient modes of production.

An investigation sponsored by the Institute of Pacific Relations published in 1933 revealed the energy inefficiencies within the cotton textile industries. Cotton milling consumed the largest share of electrical power, but its ratio of economic value to energy consumption was low. Cotton spinning and weaving consumed 34.3 percent of Shanghai's power output, while it accounted for 28.5 percent of the total value of Shanghai's industrial output. Shanghai's cotton industries took charge of the entire process of cleaning raw cotton, turning raw cotton into workable yarn, and weaving the thread into cloth. This vertical integration, according to Carles Broggi, sheltered the firms from price volatility by "producing more sophisticated products with less competition and higher prices." ${ }^{68}$ The clothing industry, too, was an equally energy-intensive sector, as it used 5.52 percent of the city's total energy output but only contributed to 3.57 percent of industrial production value. ${ }^{69}$ Despite the increased abundance of electrical power in Shanghai, many cotton mills continued to generate their own electricity. By 1933, self-supplied power accounted for 12.5 percent of motive force in Shanghai's cotton mills. The practice persisted not only because older mills continued to power their aged equipment with their own steam engines but also because mill owners remained skeptical about relying on a foreign-owned electric company to power their operations. The persistence of obsolete technology hampered the energy efficiency of Shanghai's cotton textile sector, while unequal access to electricity created resentment and distrust within Shanghai's business community.

Cotton mills outside Shanghai expanded their operations by relying on self-supplied power. The local power stations in the major cotton production centers of Wuxi, Changzhou, and Nantong suffered from chronic capital shortage, which limited their ability to acquire new generators to keep up with demand. With a combined capital of 403,000 Chinese dollars, the five power stations in Wuxi founded between 1921 and 1923 with generating capacity ranging from 10 
to $100 \mathrm{~kW}$ operated old steam and gas engines. In comparison, the Zhenxin cotton mill at Wuxi founded in 1905 with 1.25 million dollars in capital was able to afford a $1,544 \mathrm{~kW}$ steam engine. Sixteen years later, Qingfeng cotton mill, which had double the amount of capital, also opted to install a $1,000 \mathrm{~kW}$ steam engine. ${ }^{70}$

Outside the Lower Yangtze region, cotton mills continued to supply their own electricity as power demand from the cotton mills far exceeded the capacity of the local power company. When Naigai set up operations in 1916, the Qingdao Elektrizitätswerk left behind by the Germans had been destroyed during the Japanese invasion in November 1914. The Japanese administrators completed the rehabilitation only on December 1919 after they installed a 1,200 kW boiler. The big four Japanese cotton mills (Naigai, Nissei, Fuji, and Nagasaki) in Qingdao had a combined generating capacity of $50,000 \mathrm{~kW}$ in 1929 , which was ten times that of the Qingdao Power Station. ${ }^{71}$ This was also true of Chinese-owned cotton mills in Tianjin (Hebei Province) and Wuchang (Hubei Province). By 1934, cotton mills accounted for 43 percent of the generating capacity and 58 percent of energy usage of all self-supplied power within China.

Energy shortage was a major constraint on Chinese cotton mills. One cotton mill addressed this problem by building its own power station to alleviate this problem. This was Dasheng Cotton Mill in Nantong, founded by Zhang Jian, a scholar-official who resigned from the Hanlin Academy and took advantage of the late Qing reforms to venture into industrial development. With 87,852 spindles, it was the largest cotton mill outside Shanghai. As Elisabeth Köll and Qin Shao have both argued, Zhang Jian's cotton mill became a patriarchal industry and a vehicle for regional self-governance. ${ }^{72}$ The provision of electricity was crucial to Zhang Jian's vision of transforming Nantong into a "model county." Shao noted that Zhang drew up plans for a regional power station in 1920, just as his family branched out into other industries. ${ }^{73}$

Dasheng submitted an application to the National Construction Commission (NCC) of the Guomindang government in Nanjing to build its own power station in 1932. Dasheng needed at least 4,000 hp to run its 240 cloth weaving machines. As the steam engine deteriorated with age, mill owners made up for the power shortfall by installing a diesel generator. This, however, increased the fuel cost. $^{74}$ Dasheng "sought to economize the cost of electrical power" by building its own power station. ${ }^{75}$ Huang Hui, a Cornell-educated engineer at the NCC, reviewed Dasheng's application. He agreed with their assessment and concluded in his inspection report, "Although the company is near the cotton-growing areas and acquired raw materials cheaply, its production costs were still high, making it unable to compete with Japanese cotton mills and new Chinese mills." Huang 
Hui attributed the high costs to three reasons: (I) old equipment; (2) heavy interest burden; and (3) cost of maintaining the social enterprises. ${ }^{76}$

Dasheng pushed through with its plans to construct the power station, even as its revenue took a hit during the Great Depression. In 1932, the shareholders approved a funding proposal, in which Dasheng put up 30,000 Chinese dollars for start-up capital and mortgaged its assets to raise another 50,000 Chinese dollars. Dasheng petitioned the Construction Commission in March 1933 to obtain an operating license for the power station. To facilitate the transportation of electrical equipment and fuel, the new power plant was built along the Yangtze River and right next to the Number 2 cotton mill. Named the Tiansheng Port Power Station, it was equipped with one British-made boiler that generated twenty-five tons of steam every hour and two German-built generators from Allgemeine Elektricitäts-Gesellschaft (AEG) with a generating capacity of 750 $\mathrm{kW}{ }^{77}$ The new power system connected Dasheng Number I mill at the outskirts of the city with the Number 2 mill located along the Yangtze. Electricity was transmitted along fifteen kilometers of $22 \mathrm{kV}$ transmission lines, and factories along the transmission line connected themselves to the new power grid. Tiansheng Port Power Station also sold surplus power to Tongming Electric Company, which had served Nantong for three decades. Both companies maintained exclusive control over their franchise areas.

The regulatory authorities were satisfied with the performance of Dasheng's power station. Yun Zhen, the director of the Construction Commission's Electrical Bureau who took charge of electrical power infrastructure development during the war, only required minor revisions from Dasheng. When he inspected the power station with Huang Hui, Yun Zhen waived the stress test, as they found all the equipment to be in good condition. Huang Hui reported that the power station generated $80,000 \mathrm{kWh}$ daily and achieved a load factor around 97 percent, meaning almost all the generated power was utilized. The Tiansheng Harbor Power Station did not undermine the operations of the preexisting Tongming Electric Company, and Tongming lowered the electric tariffs of its users in Nantong. Dasheng Cotton Mills paid 1.65 cents per kWh and sold its surplus power to Tongming at 2.65 cents per unit. Tongming drastically reduced the electric tariffs in Nantong making its electric tariff 25 percent that of the nearby silk production center of Huzhou. ${ }^{78}$ As a result, silk weavers in Huzhou would point to the low tariffs in Nantong and accuse their local power station of price gouging.

THE ELECTRIFICATION OF cotton mills in the Lower Yangtze exemplifies the challenges facing China's industries as they pursued economic growth while 
being constrained by capital scarcity. The late Qing to Republican era saw the rapid expansion of China's industries. Tim Wright's study on China's coal industry before 1937 cites John Key Chang's findings that China's net industrial output grew at 9.4 percent per annum between 1912 and $1936 .{ }^{79}$ Aggregate numbers only tell part of the story, however. The uneven access to electricity among cotton mills in Shanghai reveals how problems of "economies of speed" shaped China's early industries. Unable to purchase electricity from the grid, mill owners decided to install obsolete machines driven by steam engines or bear the cost of maintaining the factory's electrical units. Even after the corporatization of Shanghai Power Company in 1929 lowered the cost of purchasing power from the grid, many of Shanghai's cotton mills continued to rely on their in-house power supply. The persistence of the "self-supplied power" model had little to do with maintaining operational resilience but more to do with the lack of capital. As seen in the case of Longmao, this poorly capitalized firm lacked funds to replace the old machinery of its predecessor, which led to the persistence of obsolete technology. It had to sacrifice long-term sustainability in exchange for short-term economic gains. The electrification project by Dasheng in Nantong was truly exceptional and could not be replicated by other cotton mills that lacked the financial resources or political connections.

The struggle for electrical power in the transnational colony of Shanghai also shaped conceptions about economic sovereignty in modern China. In the absence of strong institutions, capitalists of different nationalities devised ways to defend their business interests. The Shanghai Municipal Council, which was dominated by the British, had taken over the provision of electricity to ensure the prosperity of the International Settlement and safeguard the interests of ratepayers of different nationalities. Ever since it began supplying power to Chinese, Japanese, and British cotton mills in I914, the Electricity Department's impartiality had come under question. Chinese mill owners had their applications for electrical connection rejected and accused the council of granting preferential access to the Japanese and British. There were also conflicts among the non-Chinese capitalists. As we have seen, the British cut off electricity to the International Settlement with the twin objectives of forcing the Chinese and Japanese to negotiate a truce and retaliating against the Japanese for stirring up trouble that led to an anti-British boycott. The May Thirtieth Incident aroused the nationalist sentiments of both workers and capitalists alike.

Chinese intellectuals who came of age in the r920s advocated the nationalization of electrical industries to address problems of uneven access, as they witnessed the inequalities created by a power sector dominated by foreign 
capitalists. Zheng Youkui, one of China's first generation of economic historians, voiced support for this nationalistic approach to infrastructure development. In the conclusion of his study on China's pre-1949 economy, Zheng saw "an efficient, honest, and competent government" as the way to break the "logjam" of China's socioeconomic problems and urged the state to use its coercive power to interfere with anything "ranging from consumers' taste to the direction of investments and capital formation." ${ }^{80}$ The ensuing chapters discuss how economic nationalism inspired China's first generation of engineers to turn toward careers in public service, which in turn led to the rise of a highly interventionist developmental state following four decades of war and revolution.

The electrification of Shanghai's cotton mills within a compressed period of two decades marked the beginning of China's transformation into a contributor to the Great Acceleration of the Anthropocene. The Municipal Council benchmarked the Riverside Power Station's performance against five of Britain's largest power companies. By the second half of the 1920s, the number of units sold and load factor in Shanghai exceeded that of Manchester, Birmingham, Glasgow, Liverpool, and Sheffield. The factories clustered along Yangshupu Road simply bought up any additional power generated following each expansionary cycle. A process that had taken a century or so to unfold in Britain was completed within a decade in 1920s Shanghai. The growth screeched to a halt in 1941, however, after the Japanese takeover of Shanghai during the start of the Pacific War, but the foundations for accelerated development had been put in place.

The Lower Yangtze offered other models for economic growth. In the next chapter, the imperial powers that dominated the industries in Shanghai recede to the background in the silk-production center of Huzhou. Our focus is on the local elite who made use of the new energy technology to assert their control over the modes of production. Localism pervaded the energy politics of Huzhou, as its industrialists spearheaded the effort against the central government's attempt to regulate the power sector. While cotton milling fostered the rise of centralized power systems, silk weaving led to the creation of highly localized power networks that catered to the energy demands of a small locale. The national economic fabric woven by the electrified silk loom looked quite different from that created from mechanized cotton spindles. 